\title{
Prevalence of Bacterial Infection in Patients with Chronic Hepatitis C Treated and not Treated with Interferon
}

\author{
Iman.M.A.El-Kholy, ${ }^{1}$ M. H. Abdelaziz, ${ }^{2}$ S.W. Abdelsalam, ${ }^{2}$ \\ ${ }^{1}$ Ain Shams University Specialized Hospital, Cairo and \\ ${ }^{2}$ Microbiology Section, Botany Department, Faculty of Science, \\ Suez Canal University, Ismailia, 41522, Egypt
}

\begin{abstract}
7 REATMENT with interferon and ribavirin in patients with chronic hepatitis $\mathrm{C}(\mathrm{CHC})$ is the most common therapy although it is accompanied by multiple side effects. Bacterial infection represents the most common side effect. The present study aims to analyze relation between bacterial infection in patients with $\mathrm{CHC}$, interferon treatment and virulence factors of isolated bacteria. Out of 212 immunocompromised patients with hepatitis $\mathrm{C}$ hospitalized were studied for bacterial infection, the median age of patients was 50 years (range 23-83 y) of which 132 male $(62.3 \%)$ and 80 females (37.7\%). 149 patients have bacterial infection while 63 patients are negative for bacterial infection. The collected data obtained from patients showed that 92 patients $(43.5 \%)$ not treated with interferon and $120(56.6 \%)$ treated with different doses of the interferon and ribavirin,. Our results showed that the bacterial infection represents $90.8 \%$ of patients who were treated with interferon while patients who were not treated with the combined therapy showed signs of infections of $43.5 \%$. E. coli being the most frequent pathogen (25\%) followed by Acinetobacter baumannii (13.8 $\%)$. The strains were confirmed by Biolog Microlog 34.20 system. The development of bacterial infection in patients treated with interferon associated with hematological complications as anemia $(85.4 \%)$, neutropenia $(94.5 \%)$ and thrombocytopenia $(100 \%)$. Patients with $\mathrm{CHC}$ undergoing treatment with interferon and ribavirin have increased risk of develping bacterial infection as a result of bone marrow suppression.
\end{abstract}

Keywords: $\mathrm{HCV}$, Interferon treatment, Bacterial infection, Hematological complications.

Hepatitis $C$ virus is a major cause of chronic liver disease, infecting 200 Million individuals worldwide (Mc Hutchison et al., 2004). Egypt has a very high prevalence of HCV rates in several populations reached up to 20\% (Mohamed et al., 2005 and Seif El- Nasr et al., 2006), a high morbidity and mortality from chronic liver diseases, cirrhosis and hepatocellular carcinoma, and the highest prevalence of HCV-4 (67\%) with a predominance of subtype 4a (55\%) (Elkady et al., 2009 and Khattab et al., 2011).

Corresponding author: imankholy@yahoo.com 
Treatment with interferon and ribavirin in patients with chronic $\mathrm{CHC}$ represent current standard therapy, although it is accompanied by multiple side effects (Marincu et al., 2010). Leads to long-term resolution of infection in 45\%$80 \%$ of individuals, depending on viral genotype (Fried, 2002). The mechanism of action is not completely understood, but both drugs have a wide-range effects on the immune system (Barnes et al., 2004) The most common side effects of interferon and ribavirin are the hematological and immunological ones, as the most common side effect of interferon therapy is bone marrow suppression that results in a decrease of the leukocyte count(Dieterich and Spivak, 2002). Bacterial infection is a frequent and severe complication of cirrhosis that may be present on admission or developed during hospitalization in 30-60\% of hospitalized cirrhotic patients (Borzio et al., 2001). The most frequent infective complications include spontaneous bacterial peritonitis, urinary tract infections, respiratory infections, and bacteraemia, mostly due to the concomitant presence of various facilitating mechanisms such as immunological abnormalities as neutrophil dysfunction and reduction in serum bactericidal account for the increased susceptibility of chronic liver diseases patients for bacterial seeding (Runyon, 2004). Also, changes in the reticulo- endothelial system decreases the opsonic activity of the ascetic fluid, and iatrogenic factors. In fact, up to $25 \%$ of death cases in cirrhotic patients are believed to be related to bacterial infections (Yang and Lin, 2005).

Recent studies reported that multi drug resistant Enterobacteriaceae and non fermentable bacilli e.g. Pseudomonas aeruginosa (pathogens resistant to the main antibiotics, including b-lactams) are the most common infection in patients with cirrhosis showing high prevalence in different geographic areas (Fernandez et al., 2012 and Fernandez and Arroyo, 2013). Staphylococcus aureus is increasingly recognized as an important pathogen in cirrhotic patients (Chang et al., 1998). It has been shown that this organism is ranked second in frequency among causative agents of bacteremia in patients who have end-stage liver disease and are awaiting transplantation (Mccashland et al., 1994 and Singh et al., 1997). Some studies have described the distribution of the most frequent types of infection, but few studies have tried to assess whether the frequency of infection is related to interferon treatment.

\section{Materials and Methods}

\section{Clinical examination and Laboratory data}

Two hundred and twelve hospitalized patients were included in this study suffering from HCV within cirrhosis (stage II) at Ain Shams hospitals, Cairo, Egypt in the period from January 2012 till November 2012, 132 males and 80 females their ages ranged from 23 years to 83 years. The data were extracted from medical records (blood counts, alanine aminotransferase, aspartate aminotransferase, unconjugated bilirubin, conjugated bilirubin, total bilirubin, gamma-glutamyl transpeptidase, alkaline phosphatase and antibodies against the hepatitis C virus (anti-HCV), HCV RNA PCR \& Interferon doses). 


\section{Sampling and isolation}

A total number of two hundred and twelve (212) samples were collected according to (Cheesbrough, 2006) from different sites whenever signs of infections become apparent and transported to laboratory immediately. The samples are sputum, pus, urine, ascitic fluids, bile and blood samples. The strains had been isolated on different media as Nutrient agar, MacConkey agar, Mannitol salt agar and blood culture bottles (Bactec 9240).

\section{Identification of isolated bacteria}

Identification at least to genus level by MicroScan ${ }^{\circledR}$ microbiology, cultural characteristics, biochemical activities and API 20E system (bioMe'rieux, France) as well as; Confirmation of our presumptive identification by Biolog Microlog 34.20 System.

\section{Antimicrobial susceptibility test}

Antimicrobial susceptibility of the isolates was studied by the disk diffusion technique on Muller Hinton agar medium (Jorgensen et al., 1999). The interpretive criteria followed the latest National Committee for Clinical Laboratory Standards (NCCLS) recommendations NCCLS (2003).

\section{Phenotypic detection of Virulence factors of isolated bacterial species}

Proteolytic activity done by well diffusion method using skimmed- milk agar plates (10\%); while sheep blood (5\%) agar plates were used to detect hemolysis. The binding activity with Congo red dye indicating the invasion capability using Congo red agar was tested. Lipolytic activity was assessed on tween 80 agar medium and incubated for 3 days.

\section{Statistical analysis}

The collected data were tabulated and graphed by Excel program 2007 and analyzed by SPSS statistics (V.20.0, IBM Corp).

\section{Results}

Among the patients under study, a total of 132 males (62.3\%) and 80 females (37.7\%), 149 patients have bacterial infection while 63 patients are negative from total 212 hospitalized patients, 92 patients $(43.3 \%)$ did not receive interferon and ribavirin treatment, 120 patients $(56.6 \%)$ received treatment in different doses of interferon (Table 1 ). Bacterial infection represents $90.8 \%$ in patients treated with interferon, but infections recorded $43.5 \%$ in those not treated with the combined therapy. The results showed that the prevalence of bacterial infection increase with the increasing in interferon and ribavirin doses as $100 \%$ of patients who received $22-32$ doses having positive bacterial culture. 52 from 63 patients who are negative for bacterial infection are not treated with interferon, but only 11 patients from 120 patients treated with interferon and ribavirin are not have bacterial infection. That show positive correlation 
between interferon treatment and incidence of bacterial infection and high significance (P value <0.05) $($ Table 2$)$

TABLE 1. Frequency of Interferon doses and bacterial infection among the study Population.

\begin{tabular}{|c|c|c|c|c|c|}
\hline \multirow{2}{*}{ Interferon dose intervals } & \multirow{2}{*}{ Total } & \multicolumn{2}{|c|}{ Infected } & \multicolumn{2}{c|}{ Non-infected } \\
\cline { 3 - 6 } & & Count & $\%$ & Count & $\%$ \\
\hline 0 & 92 & 40 & $43.4 \%$ & 52 & $56.6 \%$ \\
\hline $1-12$ & 44 & 35 & $79.5 \%$ & 9 & $20.5 \%$ \\
\hline $12-22$ & 36 & 34 & $94.4 \%$ & 2 & $5.6 \%$ \\
\hline $22-32$ & 40 & 40 & $100 \%$ & 0 & 0 \\
\hline Total & 212 & 149 & $70.3 \%$ & 63 & $29.7 \%$ \\
\hline
\end{tabular}

TABLE 2. Prevalence of infection among the study population according to interferon treatment .

\begin{tabular}{|l|c|c|c|}
\hline Patient & Total & Infected & Non-infected \\
\hline Treated with interferon & 120 & $109(90.8 \%)$ & $11(9.2 \%)$ \\
\hline Not treated with interferon & 92 & $40(43.5 \%)$ & $52(56.5 \%)$ \\
\hline
\end{tabular}

\section{Hematological complications}

According to laboratory data of complete blood count (CBC), patients who had bacterial infection $(\mathrm{N}=149)$ suffered from hematological complications as anemia, Thrombocytopenia and Neutropenia. The results of CBC of our patients revealed that interferon and ribavirin combined treatment had suppressive effect on bone marrow and caused reduction in the production of platelets and leukocytes.

Our results showed that the high reducing effect of interferon was on neutrophil production as the incidence of neutropenia in patients who were treated with interferon compared to those who were not treated showed that the high reducing effect on neutrophil production followed by platelets production.

\section{Manifestation of Bacterial infection}

The most common site of pathogen isolation was urinary tract as all urine samples give positive culture (100\%), followed by ascetic fluid samples as 12/14 of samples are positive upon culturing. Infections of blood, bile, pus and sputum samples represent 75, 60, 57.8 and $55.4 \%$ respectively of the total samples collected from each site (Table 3). Among the bacterial infections, the most common isolated and identified species were E.coli (40 isolate) as it represent $25 \%$ of all isolates followed by Acinetobacter baumanni (13.8\%), Pseudomonas

Egypt. J. Bot., 56, No. 1 (2016) 
aeruginosa and Klebsiella pneumonia represents (12.6\%) for each one. Other bacterial species were isolated the Klebsiella terrigina (10.7\%), Staphylococcus aureus (10.7\%), staphylococcus coagulase -ve (8.2\%), Proteus mirabilis $(3.1 \%)$, Enterobacter aerogens (2.5\%) and Citrobacter sp. (0.6\%) (Table 4). Confirmation of identification by Biolog Microlog system divided Klebsiella sp. to K. pneumonia and $K$. terrigina.

TABLE 3. Prevalence of positive bacterial cultures among collected samples from different sites.

\begin{tabular}{|l|c|c|c|c|c|}
\hline Clinical specimens & Total & Positive & $\begin{array}{c}\text { \% of } \\
\text { Positive } \\
\text { Samples }\end{array}$ & Negative & $\begin{array}{c}\text { \% of } \\
\text { Negative } \\
\text { samples }\end{array}$ \\
\hline Urine & 48 & 48 & 100 & 0 & 0 \\
\hline Blood & 24 & 18 & 75 & 6 & 25 \\
\hline Ascitic fluid & 14 & 12 & 85.7 & 2 & 14.3 \\
\hline Bile & 5 & 3 & 60 & 2 & 40 \\
\hline Pus & 38 & 22 & 57.8 & 16 & 42.1 \\
\hline Sputum & 83 & 46 & 55.4 & 37 & 44.5 \\
\hline Total & 212 & 149 & 70.3 & 63 & 29.7 \\
\hline
\end{tabular}

TABLE 4. Prevalence of Bacterial species in respective to infection sites.

\begin{tabular}{|c|c|c|c|c|c|c|c|c|}
\hline \multirow{2}{*}{$\begin{array}{l}\text { Isolated } \\
\text { Species }\end{array}$} & \multicolumn{6}{|c|}{ Clinical Presentation } & \multirow{2}{*}{ Total } & \multirow{2}{*}{$\%$} \\
\hline & RI & Bacterimia & SBP & Dis & PTI & Cutaneous & & \\
\hline E.coli & 29 & 1 & 3 & 1 & 2 & 4 & 40 & 25.2 \\
\hline $\begin{array}{l}\text { Pseudomonas } \\
\text { aeruginosa }\end{array}$ & 5 & 1 & 2 & 1 & 7 & 3 & 20 & 12.6 \\
\hline $\begin{array}{l}\text { Staphylococcus } \\
\text { aureus }\end{array}$ & 0 & 5 & 1 & 0 & 9 & 2 & 17 & 10.7 \\
\hline $\begin{array}{l}\text { Staphylococcus } \\
\text { coaggulase -ve }\end{array}$ & 3 & 7 & 0 & 0 & 3 & 0 & 13 & 8.2 \\
\hline $\begin{array}{l}\text { Acinetobacter } \\
\text { baumannii }\end{array}$ & 3 & 1 & 2 & 1 & 13 & 2 & 22 & 13.8 \\
\hline $\begin{array}{l}\text { Proteus } \\
\text { mirabilis } \\
\end{array}$ & 0 & 0 & 0 & 0 & 0 & 5 & 5 & 3.1 \\
\hline $\begin{array}{l}\text { Klebsiella } \\
\text { pneumonia }\end{array}$ & 6 & 0 & 2 & 0 & 12 & 2 & 20 & 12.6 \\
\hline $\begin{array}{l}\text { Klebsiella } \\
\text { terrigina }\end{array}$ & 2 & 4 & 2 & 0 & 3 & 4 & 17 & 10.7 \\
\hline $\begin{array}{l}\text { Enterobacter } \\
\text { aerogens }\end{array}$ & 0 & 0 & 0 & 0 & 2 & 3 & 4 & 2.5 \\
\hline Citrobacter & 1 & 0 & 0 & 0 & 0 & 0 & 1 & 0.6 \\
\hline Total & 49 & 19 & 12 & 3 & 51 & 25 & 159 & 100 \\
\hline
\end{tabular}

$\mathrm{RI}=$ Renal infection, $\mathrm{SBP}=$ Spontaneous bacterial peritonitis,

$\mathrm{PTI}=$ Pulmonary tract infection, $\mathrm{Dis}=$ Disseminated infection 
Suscibtibility of identified bacterial species to antibiotics

The antibiotics suscebtibility patterns of isolated bacteria were listed in Table 5. It is important to notice that all isolated bacterial species are Multi- drug resistant (MDR) , especially Acinetobacter baumannii which is resistant to all antibiotics followed by E.coli and Pseudomonas aeroginosa. Impenam is considered the most effective antibiotic to isolated species.

TABLE 5. Antibiotic susceptibility profiles of isolated bacterial species.

\begin{tabular}{|l|c|c|c|c|c|c|c|c|}
\hline \multirow{2}{*}{ Bacterial species } & \multicolumn{7}{|c|}{ Antibiotics } \\
\cline { 2 - 11 } & IPM & AMC & AK & P & CAZ & GM & LEV & TZP \\
\hline E.coli & ++ & - & - & - & - & ++ & - & - \\
\hline Klebsiella spp. & +++ & - & + & - & - & ++ & - & + \\
\hline Enterobacter aerogens & ++ & + & + & - & ++ & - & - & + \\
\hline Citrobacter sp. & ++ & + & - & - & - & - & - & + \\
\hline Pseudomonas aeroginosa & - & - & + & - & - & - & + & - \\
\hline Acinetobacter baumannii & - & - & - & - & - & - & - & - \\
\hline Proteus mirabilis & + & ++ & - & - & - & - & - & + \\
\hline Staphylococcus spp. & - & - & ++ & - & - & ++ & - & + \\
\hline
\end{tabular}

Impenam (IPM) , Augmentin (AMC) , Amikacin (AK), Penicillin (P), Ceftazidim (CAZ) Gentamycin (GM), Levofloxacin (LEV), Tazocin (TZP)

$(++)=$ highly sensitive $(+)=$ sensitive $(-)=$ resistant

Phenotypic detection of virulence factors

All isolates were subjected to simplified phenotypic tests as described in Table 6 . The three pattern of blood heamolysis $\alpha, \beta$ and $\gamma$ were detected by the identified species . $\beta$ heamolysis represents the most common pattern of $\alpha$-heamolysis. Proteolytic activity of all isolated bacterial species was expressed by mean diameter of clearing zone. All bacterial species were able to hydrolyze protiens (produce proteases enzymes). All isolates have the ability to produce lipase enzyme ecxept E.coli, Acinetobacter baumannii and Entrobacter aerogens. The results of congo red binding activity taken after $24 \mathrm{hr}$ of incubation revealed that Acinetobacter baumannii, Klebsiella pneumonia and Staphylococcus aureus have strong binding activity.

TABLE 6. Phenotypic characteristics of bacterial isolates.

\begin{tabular}{|c|c|c|c|c|c|c|c|c|}
\hline 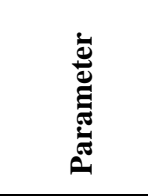 & 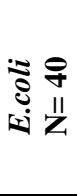 & 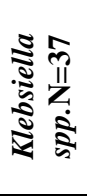 & 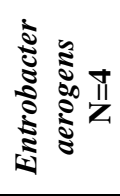 & $\begin{array}{l}\vdots \\
\vdots \\
\vdots \\
\vdots \\
\vdots \\
\vdots \\
\vdots \\
\vdots \\
0\end{array}$ & 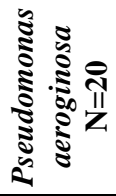 & 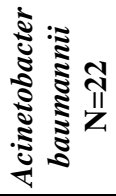 & 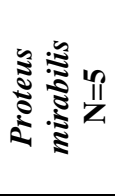 & 离 \\
\hline Heamolysis & $\beta$ & $\alpha$ & $\alpha$ & B & B & $\Gamma$ & $\beta$ & $\beta$ \\
\hline Lipase & - & + & - & + & + & - & + & + \\
\hline Proteolytic & + & + & + & + & + & + & - & + \\
\hline Catalase & + & + & + & + & + & + & + & + \\
\hline Congo red & - & + & - & - & - & + & - & + \\
\hline
\end{tabular}

$\mathrm{N}=$ number of isolates. 


\section{Discussion}

Chronic liver diseases (CLDs) are defined as the continuity of clinical and biochemical evidence of hepatic dysfunction for longer than six months (Suchy, 1996). Egypt has a very high prevalence of HCV as well as high morbidity and mortality from chronic liver disease, cirrhosis, and hepatocellular carcinoma (WHO 2013). Bacterial infection is a frequent complication in patients with chronic liver diseases mainly during the advanced stages. There is evidence that the main factors that contribute to a predisposition to infection in patients are related to hepatic failure with consequent immunodeficiency (Delvone et al., 2001). 149 out of 212 patients are positive for bacterial infection (70.3\%) while 63 are negative of patients (29.7\%). The results showed that the prevalence of bacterial infection increases with the increasing of interferon and ribavirin doses (Soza et al., 2002), and they also show relation between bacterial infection, incidence of thrombocytopenia (100\%) and anemia (85.8\%). Marincu et al. (2010) reported that $77.3 \%$ of acute bacterial infection occurred during therapy with interferon and ribavirin was associated with neutropenia .In our study, neutropenia represented $94.5 \%$ of patients who were treated with interferon and rabavirin (IR) and they are having bacterial infection. Ferreira et al. (2012) and Mattos et al. (2003) reported that urinary tract infection represented $31.8 \%$ between cirrhotic patients.This was in agreement with our results which showed that urinary tract infection was $32.2 \%$ among the study population.

Our data showed that $E$. coli was the predominant pathogen that implicated in incidence of urinary tract infection followed by Klebsiella sp. (Klebsiella pneumonia and Klebsiella terrigina). These findings were supported by Fatima et al. (2012). Respiratory tract infection was represented by $30.8 \%$ (46 out of 149 cases) among our study population. These finding were closely in agreement with that reported by Fried (2002). On the contrary, Ferreira et al. (2012) reported that respiratory tract infection represent $15 \%$ among his study population .Our study and other studies provided evidence that gram negative bacilli and staphylococci were the most common bacterial species implicated in respiratory tract infection (Cheruvattath and Balan 2007). Spontaneous bacterial peritonitis (SBP) was a frequent and a serious complication that occurs in 10-30\% of patients with cirrhosis and ascites (Garcia-Tsao, 2005 and Navasa et al.,1997) which mainly was caused by enteric bacteria particularly Escherichia coli (Bert et al., 2005 and Park et al., 2007) while in our study SBP represent only $8 \%$ (12 of 149 cases) of bacterial infections.

Proteus was a common cause of wound infections in West Africa. Orrett (1999) and Resliniski et al. (2005) they showed Proteus species to be more commonly encountered in urine than in other clinical specimens. In our study Proteus mirabilis was the most predominant isolated bacterial species implicated in cutaneous infection, these finding was supported by Mansy (2001) and 
Bahashwan and El-shafey (2013) who reported P. mirabilis to have been implicated in nosocomial infections of the surgical wounds and lower respiratory tract.

In our study, through identification by (Biolog Microlog 34.20 system) it appeared that Klebsiella sp. was divided into K. pneumonia and K. terrigina. $K$. terrigina is considered a new species for us to be isolated from clinical samples expressing virulence factors and showing pathogenicity closure, to some extent, to that expressed by K. pneumonia about of 20 years ago after its first description. The reports on the isolation of $K$. terrigena from human clinical specimens were considered remarkably rare (Podschun et al., 2000).

Staphylococcus aureus was an important pathogen in cirrhotic patients (Chang et al., 1998), most common causative agents of bacteremia in patients who have end-stage of liver disease and are awaiting transplantation (Mccashland et al., 1994 and Singh, 1997). In our results, gram positive cocci (mainly Staphylococcus aureus) represented $18.8 \%$ of bacterial infections and is considered the main cause of bacterimia as well as showing high prevalence in respiratory infection. Staphylococcal infection can also occur in other sites as ascetic fluid and cutaneous infection. Nasal carriage of $S$. aureus played an important role in the epidemiology and pathogenesis of infection and may account for the recurrence of infections at multiple sites (Kluytmans et al., 1997 and Voss \& Doebbeling 1995). Acinetobacter baumannii was the most prevalent pathogen among our isolation sites. It is considered the most prevalent pathogen in sputum samples and implicated in respiratory tract infection. This observation was in agreement with Henwood et al. (2002) who found high isolation rate of Acinetobacter buamanni from sputum samples that was associated with lower respiratory tract infection. Our results showed that members of Enterobacteriaceae have different patterns of susceptibility to different antibiotics. E.coli and Klebsiella $s p$. show high degree of sensitivity to group of carbapenems members (Impenam IPM and Meropenem MEM) and high resistance was recorded to Cephalosporins generation 4 (Maxipime FEP) and Cephalosporine generation 3 (Cefotaxime CTX). The highest sensitivity was been showed by Enterobacter aerogens to most antibiotics with degree more than $50 \%$. On the other hand, Proteus mirabilis showed high resistance pattern to majority of antibiotics . Pseudomona aeroginosa lay between $30 \%$ to $70 \%$ against to the investigated antibiotics and complete resistance to Augmentin (AMC) and Doxycylin (DO). These results are in agreement with Fernandez et al. (2012)who demonstrated that the data from different geographical areas show an increased prevalence of infections caused by multiresistant bacteria in cirrhosis (pathogens resistant to the main antibiotics, including b-lactams). The most common organisms, Enterobacteriaceae, nonfermentable gram negative bacilli (e.g., Pseudomonas aeruginosa), produced spectrum b-lactamase.

Acinetobacter baumannii was considered the most resistant bacterial species in our study whose sensitivity to different antibiotics does not exceeds $23 \%$, this percentage of sensitivity appears with Ceftazidime, Amikacin and Sulperazon. Henwood et al. (2002) in United kingdom demonstrated that Acinetobacter

Egypt. J. Bot., 56, No. 1 (2016) 
baumannii clinical isolates show less resistance to amikacin than other used antibiotics, but over $75 \%$ of isolates were resistant to Ceftazidime. They also reported that the only established drugs active against $90 \%$ of isolates are Carbapenems. In our study, Acinetobacter baummanni isolates showed high sensitivity to combination of two antibiotics not to Carbapenems only. On the other hand a recent study done by Fouad et al. (2013) in Egypt who demonstrated that $74 \%$ of Acinetobacter baummanni isolated from different hospitals were resistant to Carbapenems. Staphylococcus aureus isolates were sensitive to Vancomycin followed by Tiecoplanin and showed low sensitivity to Penicillin and Tetracyclin. These results were in agreement with that reported by Trkyilmaz \& Eskuuzmurler (2006), they found all isolated Staphylococcus aureus were sensitive to Vancomycin and have $49 \%$ resistance to Penicillin. We found that all isolates studied of bacterial species showed positive proteolytic activity with different diameters of the clearing zones. Staphylococcus coagulase -ve and E.coli have the highest proteolytic activity as Castro et al. (2003) stated that protease production was prevalent in clinical isolates than environmental since protease is important to colonization in host cell. They stated that protease is a major virulence enzyme in the isolates. Our results of Congo red test showed that all isolated bacterial spp as (E.coli, Pseudomonas aeroginosa, Acinetobacter baumanii, Klebsiella spp. Staphylococcus spp. and Enterobacter aerogens) were both able slim production and invasion, while Proteus mirabilis and Citrobacter spp were lost this ability. The high potency of slim production appeared by Acinetobacter baumanni (77\%) followed by Staphylococcus coagulase -ve isolates $(76 \%)$ in agreement with Cevahir et al. (2008) who found that most isolates had the ability for biofilm production and considered that to be one of the reasons for the multi-drug resistance showed by A.baumannii. Trkyilmaz and Eskuuzmurler (2006) reported that slim production detected by Congo red agar represented 77\% between Staphylococcus aureus isolates. It was noticed that all abcterial species were multi drug resistant (MDR). Most of our bacterial species were resistant to three antibiotics or more. This is in accordance with Mulla and Jethwani (2012) who were recorded that percentage of resistance was $100 \%$ in Acinetobacter baumannii and $37.5 \%$ in Enterobacter aerogens. The current results of phenotypic virulence factors indicated that there is a relation between biofilm formation and the resistance to antibiotics. Acinetobacter baumannii represented the most resistant species to antibiotics and had the highest ability for slim production.

Acknowledgement: The authors would like to thank the physicians of Ain Shams University Hospital for their support and assistance in collecting work samples.

\section{References}

Bahashwan, A.S. and El-Shafey, M.H. (2013) Antimicrobial resistance patterns of proteus isolates from clinical Specimens. European Scientific Journal. 9 (27), 188- 202. 
Barnes, E., Salio, M. and Cerundolo, V. (2004) Impact of alpha interferon and ribavirin on the function of maturing dendritic cells. Antimicrob Agents Chemother. 48 (9), 3382-9.

Bert, F., Noussair, L., Lambert-Zechovsky, N. and Valla, D. (2005) Viridans group streptococci: an underestimated cause of spontaneous bacterial peritonitis in cirrhotic patients with ascites. Eur. J. Gastroenterol Hepatol, 17 (9), 929-33.

Borzio, M., Salerno, F. and Piantoni, L. (2001) Bacterial infection in patients with advanced cirrhosis: a multicenter prospective study. Digest liver Dis .J. 33, 41-48.

Castro-Escarpulli, G., Figueras, M.J., Aguilera-Arrelo G., Soler, L. and Fernandezrandon, E. (2003) Characterization of aeromonas sp. isolated from frozen fish intended for human consumption in Mexico. Int. J. Food. Microbial. 84, 41-49.

Cevahir, N., Demir, M., Kaleli, I. and Gurbuz, M. (2008) Evaluation of biofilm production, gelatinase activity and mannose resistant hemaggultination in Acinetobacter baumannii strains. Journal of microbiology Immunol Infect., 41, 513-518.

Chang, F.Y., Singh, N., Gayowski, T.,Gayowski, T., Wagener, M.M., Marino, I.R. (1998) Staphylococcus aureus nasal colonisation in patients with cirrhosis: prospective assessment of association with infection. Infect. Control. Hosp. Epidemiol., 19, 328-32.

Cheesbrough, M, (2006) "District Laboratory Practice in Tropical Countries". $2^{\text {nd }}$ ed. United Kingdom: Cambridge University press.13-23.

Cheruvattath, R. and Balan, V. (2007) Infections in patients with end-stage Liver Disease. J. Clin. Gastroenterol. 41, 403-411.

Delvone, A., Antônio, A. and Lopes, R. (2001) Comparative Study of Bacterial Infection Prevalence Between Cirrhotic Patients With and Without Upper Gastrointestinal Bleeding. The Brazilian Journal of Infectious Diseases. 5 (3), 136-142.

Dieterich, D.T., Spivak, J.L. (2002) Hematologic disorder associated with hepatitis C virus infection and their management. Clin. Infect. Dis. 37, 533-41.

Elkady, A., Tanaka, Y., Kurbanov, F. Sugauchi, F., Sugiyama, M. and Khan, A. (2009) Genetic variability of hepatitis C virus in South Egypt and its possible clinical implication. J. Med. Virol. 81, 1015-23.

Fatima, N., Agrawal, M., Shukla, I. and Khan, P.A. (2012) Characterization of uropathogenic E. coli in relation to virulence factors. Open Access Scientific Reports. 1 (7), 1-4.

Fernandez, J. and Arroyo, V. (2013) Bacterial infections in cirrhosis: a growing problem with significant implications. clinical liver disease. An Official Learning Resource of AASLD. 2 (3), 102-105.

Fernandez, J. and Gustot, T. (2012) Management of bacterial infections in cirrhosis. $J$. Hepatol. 56 (1), 1-12.

Fernandez, J., Acevedo, J., Castro, M., Garcia, O., Rodrigiguez, C. and Roca, D. (2012) Prevalence and risk factors of infections by multiresistant bacteria in cirrhosis: a prospective study. Hepatology. 55, 1551-1561.

Egypt. J. Bot., 56, No. 1 (2016) 
Ferreira, T.S., Sevá-Pereira, T., Almeida, G., Fioravante, M.I., Yamanaka, A. and Soaews, E.C. (2012) Impact of infection inhospitalized cirrhotic patients in a university hospital. Open Journal of Gastroenterology. 2, 124-130.

Fouad, M., Attia, A.S., Tawakkol, W.M. and Abdelgawad, M.H. (2013) Emergence of carbapenem-resistant Acinetobacter baumanniiharboring the OXA-2 carbapenemase in intensive care units of Egyptian hospitals. International Journal of Infectious Diseases. 17 (12), 252-1254.

Fried, M.W. (2002) Side effects of therapy of hepatitis C and their management. Hepatology. 36, 237-44.

Garcia-Tsao, G. (2005) Bacterial infections in cirrhosis: treatment and prophylaxis. J. Hepatol. 42, 585-592.

Henwood, C.J., Gatword, T., Warner, M., James, D., Stockdale, M.W., Spence, R.P., Towner, K.J., Livermore, D.M., Woodford, N. (2002) Antibiotic resistance among clinical isolates of Acinetobacter in the UK, and in vitro evaluation of tigecycline (GAR936). journal of Antimicrobial chemotherapy, 49, 479-487.

Jorgensen, J.H., Turnide, J.D. and Washington, J.A. (1999) Antibacterial susceptibility tests: Dilution and Disk diffusion Methods. In: "Manual of Clinical Microbiology" ; $7^{\text {th }}$ ed. Murry, P.R. Pfllar, F.C., Tenover, E.J. Baron, M.A. and Yolken, R.H. (Eds.); ASM press ; Washingtone ; D.C.1526-1543.

Khattab, M.A., Ferenci, P., Hadziyannis, S.J.,Colombo,M., Manns, M.P. and Almasio, P.L. (2011) Management of hepatitis $C$ virus genotype 4: recommendations of an international expert panel. J. Hepatol., 54, 1250-62.

Kluytmans, J., Van Belkum, A. and Verbrugh, H. (1997) Nasal carriage of Staphylococcus aureus: epidemiology, underlying mechanisms, and associated risks. Clin. Microbiol. Rev., $10,505-20$.

Mansy, M.S.M. (2001) Genomic fingerprinting using random amplified polymorphic DNA for discrimination between Pr. mirabilis strains. Egypt. J. Biotech., 9, 67-79.

Marincu, I., Negruţiu, L., Iacobiciu, I., Neghina,R.,Laitin, S. and Neghina, A.M. (2010). Bacterial infections in patients with chronic hepatitis $\mathrm{c}$ treated with peginterferon and ribavirin, Therapeutics, Pharmacology and Clinical Toxicology, XIV. 4, 274-278.

Mattos, A.A. (2003) Bacterial infection in cirrhotic patient. Open Journal of Gastroenterology. 40, 11-15.

Mccashland, T.M., Sorrell, M.F. and Zetterman, R.K. (1994) Bacterial endocarditis in patients with chronic liver disease. Am. J. Gastroenterol. 89, 924-7. 
McHutchison, J., Anouk, D. and Patel, K. (2004) A comparison of land mark trials for the current treatment of hepatitis $\mathrm{C}$ and the need for a head to head comparison. Hepatology., $\mathbf{1}$, $5-12$

Mohamed, M.K., Abd-elhamid, M., Mikhail, M.M. andAbd El-Aziz, F. (2005) Intrafamilial transmission of HCV in Egypt. Hepatology. 42, 683-7.

Mohamoud, Y., Mumtaz, G., Riome, S., Miller, D. and Abu-Raddad, L. (2013) The epidemiology of hepatitis C virus in Egypt: a systematic review and data synthesis. BMC Infectious Diseases, 13, 1-21.

Mulla-Summaiya, A. and Jethwani-Urmi, N. (2012) Assessment of biofilm formation by the causative organisms of ventilatior associated pneumonia at intensive care unit of a tertiary care hospital; National journal of Medidcal Research, 2 (1), 2249-4995.

Navasa, M., Rimola, A. and Rodés, J. (1997) Bacterial infections in liver disease. Semin Liver Dis., 17, 323-33.

NCCLS (2003) National Committee for Clinical Laboratory Standards (NCCLS) recommendations.

Orrett, F.A. (1999) Prevalence of Proteus species in urinary tract infections in a regional hospital in Trinidad. Zhonghua Yi Xue Za Zhi (Taipei). 62, 438-442.

Park, M.K., Lee, J.H., Byun, Y.H. and Lee, H.I. (2007) Changes in the profiles of causative agents and antibiotic resistance rate for spontaneous bacterial peritonitis: an analysis of cultured microorganisms in recent 12 years. Korean. J. Hepatol. 13(3), 370-377.

Podschun, R., Fischer, A. and Ullmann, U. (2000) Characterization of Klebsiella terrigena strains from humans:haemagglutinins, serum resistance, siderophore synthes and serotypes. Epidemiol. Infect., 46,125-132.

Reslinski, A., Gospodarek., E. and Mikucha, A. (2005) Prevalence of multi-drug resistant Proteus species in clinical specimens and their susceptibility to antibiotics. Med. Dosw. Micribial. 57 (2), 175-184.

Runyon, B.A. (2004) Management of adult patients with ascites caused by cirrhosis. Hepatology. 27, 264-72.

Seif, El-Nasr, M.S., Wahib, A.A., Mangoud, A.M., El shazly, A.M. and Morsy,A.T. (2006). HCV/PCR positivity in bile and duodenal aspiration of fascioliasis and HCV patients. $J$. Egypt. Soc. Parasitol. 3, 779-94.

Singh, N., Yu, V.L., Wagener, M.M. and Gayowski, T. (1997) Cirrhotic fever in the1990s: a prospective study with clinical implications. Clin. Infect. Dis., 24, 1135-8.

Soza, A., Everhart James, E. and Ghany Marc, G. (2002) Neutropenia during combination therapy of interferon alfa and ribavirin for chronic hepatitis C. Hepatology, 36, 1273-9.

Suchy, F.J. (1996) Chronic viral hepatitis in children. semin. pediatr. gastroenterol. Nutr. 2, 914.

Egypt. J. Bot., 56, No. 1 (2016) 
Turkyilmaz, S. and Eskü̈üzmürlüler, S. (2006) Detection of slime factor production and antibiotic resistance in staphylococcus strains isolated from various animal clinical samples. Turk. J. Vet. Anim. Sci. 30, 201-206.

Voss, A. and Doebbeling, B.N. (1995) The worldwide prevalence of methicillin-resistant Staphylococcus aureus. Int. J. Antimicrob Agents., 5, 101-106.

WHO (2013) World Health Oranization. Hepatitis C. Updated July. Available at http://www.who.int/ mediacentre/ factsheets/ fs164/en/index.html.

Yang, Y.Y. and Lin, C.H. (2005) Bacterial Infections in Patients with Cirrhosis. $J$. Chin. Med. Assoc., 68 (10), 447-451.

(Received 11/6/ 2015;

accepted 30/ 9/2015 


\title{
تواجد الالتهاب البكتيرى فى مرضى الالتهاب الكبدى الوبائى المزمن سى المعالجين والغير معالجين بالإنترفيرون الابني
}

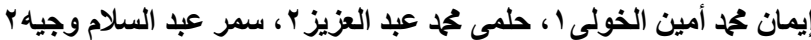

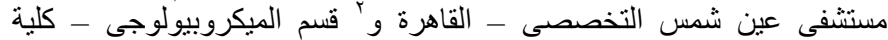 \\ العلوم، جامعة قناة السويس الإسماعيلية ـ- مصر.
}

يُعد العلاج بالانترفيرون وريبا فيرين فى المرض الذين يعانون من التهاب الكبد

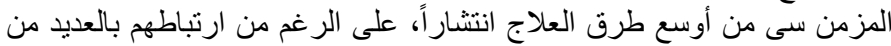
الآثار الجانبية.

وقد وجُد أن العدوى البكترية تمثل الجانب الأكبر والأكثر شيوعاً فى الآثار

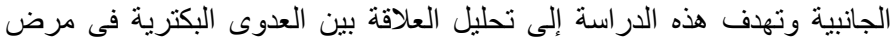

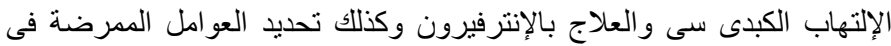

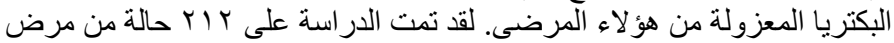

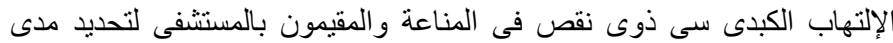

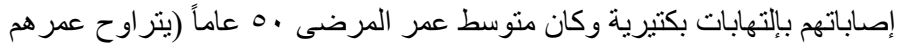

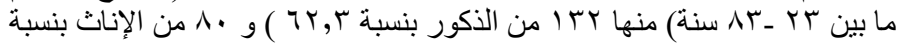

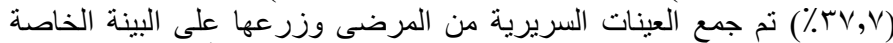

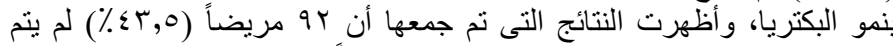

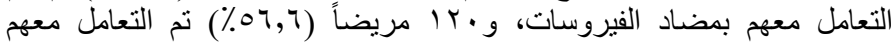

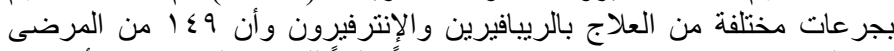

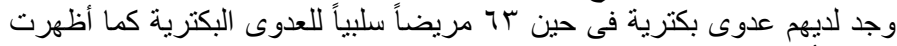

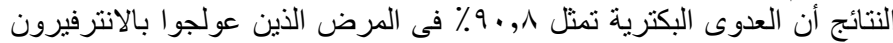

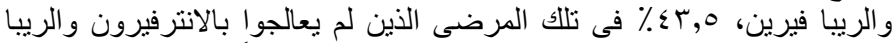

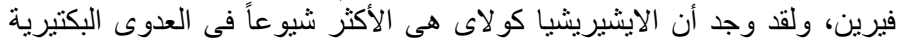

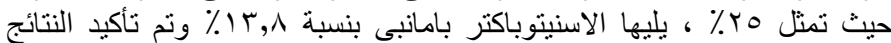

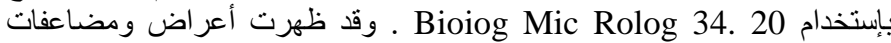

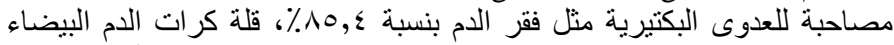

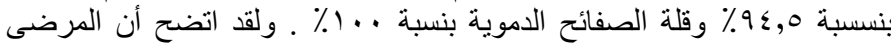

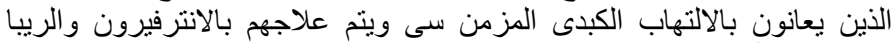

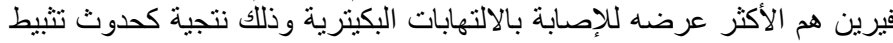
بالنخاع العظمى الناتج من العلاج بمضادات الفيروسية. 